\title{
Optimization of Differential pH Sensors Device Operation Conditions to Be Used in Quantification of Low Glucose Concentration
}

\author{
Najah M. Mohammed Al-Mhanna \\ Institute of Bioprocess Engineering, Department of chemical and bioengineering \\ University of Erlangen-Nuernberg, Paul-Gordan Str. 3, 91052 Erlangen, Germany \\ Tel: 499-131-852-3017Ｅ-mail: najah.mohammed@bvt.cbi.uni-erlangen.de, najah.almhanna@yahoo.de
}

Received: August 10,2010 Accepted: August 24, 2010 doi:10.5539/ijc.v3n2p149

This work was sported by Institute of Bioprocess Engineering at Erlangen University where the work was done

\begin{abstract}
The aim of this study is to find optima of operating conditions of phosphorylation enzymatic reaction of glucose within differential $\mathrm{pH}$ sensors device. Five variables were studied, i.e., amount of enzyme (7.45-44.7 $\mu \mathrm{l})$, buffer concentration (20-50mM), $\mathrm{pH}$ of buffer (6.8 to 8.1$)$, ATP concentration $(0.2-2 \mathrm{mM})$ and $\mathrm{Mg}^{+2}$ concentration $(1.2$ to $6 \mathrm{mM})$.

The kinetic study indicated optima of amount of enzyme of $(30 \mu \mathrm{l})$, buffer concentration of $(40 \mathrm{mM})$, $\mathrm{pH}$ value of buffer of (7.6), ATP concentration of $(1.2 \mathrm{mM})$ and $\mathrm{Mg}^{2+}$ concentration of $(2.2 \mathrm{mM})$ for phosphorylation of $1 \mathrm{~g} / 1$ glucose concentration sample. A calibration curve of glucose quantification was done for low glucose concentration range i.e. from 0 to $1 \mathrm{~g} / \mathrm{l}$. This low range makes the assay of this study efficient to be used in many applications. For instance, the assay can be used in glucose quantification during cultivation of variety kinds of cells at low glucose concentration. The assay was developed by using HEPES buffer as new carrying buffer system.
\end{abstract}

Keywords: Optimization, Differential pH Sensors Device, Quantification, Low Glucose Concentration

\section{Introduction}

Determining glucose concentration for many applications was done by using different methods such as gas chromatography-mass spectrometry, HPLC, electrochemical and enzymatic assay (Mosca et al, 1981; Xie et al, 2009; Diessel et al, 2004; Ciantar et al, 2002; Boduroglu et al, 2005; Barrado et al, 1999; Mori et al, 1999; Wahjudi et al, 2010).

Since enzymatic assay needs non expensive apparatus, it is widely applied. Differential $\mathrm{pH}$ device of two $\mathrm{pH}$ sensors was developed to meet the need of simple and cheap glucose assay. The use of this device depends on measuring the change in $\mathrm{pH}$ of solution which is caused by phosphorylation of glucose. Hexokinase enzyme is used to achieve this reaction in the presence of ATP and $\mathrm{Mg}^{2+}$ at optimum alkali $\mathrm{pH}$. It is similar to glucose phosphorylation reaction that takes place in virtually all organisms. Also phosphorylation of glucose is the first step of glycolysis process which leads to phosphorylate glucose at 6 position to yield glucose 6-phosphate at the expense of ATP. This reaction is found in most animal, plant, microbial cells (Lehninger, 1987). The mechanism of phosphorylation reaction of glucose can be seen in the following reaction:

$$
\text { D-Glucose }+\left(\mathrm{ATP}-\mathrm{Mg}^{+2}\right) \longrightarrow \text { GK } \longrightarrow \text { Glucose-6-Phosphate }+\mathrm{ADP}+\mathrm{H}^{+}
$$

Therefore, librated $\mathrm{H}^{+}$will cause change in $\mathrm{pH}$ of solution leading to get less $\mathrm{pH}$. As the device includes two $\mathrm{pH}$ sensors, one is used to measure the $\mathrm{pH}$ of solution before adding enzyme while the second sensor will measure the $\mathrm{pH}$ after adding the enzyme. The difference between values of $\mathrm{pH}$, before and after glucose phosphorylation enzymatic reaction, will be monitored by computer Manger program. Figure (1) represents the schematic diagram of differential $\mathrm{pH}$ device. Also details on the device work, set up, its applications can be found in different publications (Luzzana and Dossi, 1983; Rovida et al 1984; Luzzana and Agnellini, 2001).

Since many earlier researches of glucose determination by using differential $\mathrm{pH}$ device applied published optima of glucose phosphorylation, the aim of this study is to find the optimum operating conditions of glucose quantification within differential $\mathrm{pH}$ device. Also the use of this device was limited for high glucose 
concentration i.e. above $1 \mathrm{~g} / \mathrm{l}$. This limitation in concentration makes this device not widely used. Many of kinetics studies of cells cultivation needs to observe glucose consumption below $1 \mathrm{~g} / \mathrm{l}$. Therefore, it was intended to develop an assay for low glucose concentration samples i.e. below $1 \mathrm{~g} / \mathrm{l}$. Such low concentration range can be used for assaying high glucose concentration samples too. However, high glucose content samples have to be diluted. Finally, developing the measurement by using new buffering system, HEPES buffer was determined.

\section{Experimental Procedure}

\subsection{Materials}

Glucose powder of molecular weight (198.18) was used in preparing standard glucose samples. These samples of different concentrations $(0-1 \mathrm{~g} / \mathrm{l})$ were obtained by dissolving glucose powder in bidest water of 0.005 microsiemens $(\mu \mathrm{S})$. Adenosine triphosphates (ATP) and hexokinase enzyme (HK) were purchased from Sigma-Aldrich Company. HEPES buffer at different $\mathrm{pH}$ was used as carrying reaction solution. Solution of hexokinase enzyme of final activity of $564 \mathrm{U} / \mathrm{ml}$ was prepared by dissolving enzyme in a mixture of $25 \%$ of glycerol/water.

\subsection{Instruments}

\subsubsection{Differential $\mathrm{pH}$ analyzer system CL10 (Eurochem, Italy).}

The main parts of this apparatus are two capillary glass electrodes of $\mathrm{pH}$ sensors for detecting $\mathrm{pH}$ value of solution. Mixing chamber of $1090 \mu 1$ maximum volume is occurred as small reactor to achieve glucose phosphorylation. Five peristaltic pumps are available for pumping desired solutions e.g. buffer, enzyme and to execute washing step. This device is controlled by using the CL10 Manger program

\subsection{Procedure}

During this study the temperature of differential $\mathrm{pH}$ device was held constant at $30^{\circ} \mathrm{C}$. A waiting time of 4 seconds before each measurement was applied. Maximum reaction time of 300 seconds (cycle time) of differential $\mathrm{pH}$ device was used. In order to check the stability of device, first runs were done with buffer only. A same procedure was repeated for all variables. This procedure includes injecting of $120 \mu 1$ of glucose sample of $1 \mathrm{~g} / \mathrm{l}$ concentration into $780 \mu \mathrm{l}$ buffer within the mixing chamber of differential $\mathrm{pH}$ device. The measurement cycle was started and about $435 \mu \mathrm{l}$ of this solution were then automatically distributed into electrodes 1 and 2 . Defined amount of hexokinase enzyme was added to the remaining solution in mixing chamber according to each run set up. The difference in $\mathrm{pH}$ of electrode 1 and electrode 2 was observed. The $\mathrm{pH}$ deviation is a result of phosphorylation reaction of glucose which will induce $\mathrm{H}^{+}$into solution.

\section{Results and discussion}

In this optimization study, standard glucose samples of $1 \mathrm{~g} / \mathrm{l}$ concentration were used. It was intend to make a calibration curve of glucose concentration up to $1 \mathrm{~g} / \mathrm{l}$ in order to be used in assaying glucose samples of low concentration and high concentration as well.

Total enzyme activity is an estimate of the amount of enzyme present if assay conditions, including concentrations of substrates, are kept nearly constant. This is due to the establishment of pseudo-zero-order reactions which means that rates of reactions are dependent solely on the enzyme concentration (Rogers and Gibon, 2009).

Kinetics study was started by varying the amount of used hexokinase enzyme of final activity of $564 \mathrm{U} / \mathrm{ml}$. The range of enzyme amounts was $(7.45-44.7 \mu \mathrm{l})$ at constant other parameters such as ATP concentration of $1.2 \mathrm{mM}$, $20 \mathrm{mM}$ HEPES buffer at $\mathrm{pH} 7.6$ and $2.2 \mathrm{mM}$ of $\mathrm{Mg}^{2+}$. Enzyme activity is related to enzyme concentration and it was observed by measuring the obtained change in $\mathrm{pH}$. Enzyme activity was proportional to the amount of enzyme present. The results showed that the required time of reaching end point of glucose phosphorylation was decreased from $240 \mathrm{sec}$ to $32 \mathrm{sec}$ when enzyme volume was increased from $7.45 \mu$ to $44.7 \mu 1$ respectively. This reduction in time was on expense of maximum obtained change in $\mathrm{pH}$ as it was decreased also from $(-55.2 \mathrm{mpH}$ to $17.8 \mathrm{mpH}$ ) as shown in figure (2). Increasing enzyme volume acted as a diluting solution for samples and caused lowering of obtained change in $\mathrm{pH}$. In order to define the required amount of enzyme (volume), rates of reaction against enzyme amount were studied. Rate of reaction, enzyme activity, was calculated from obtained change in $\mathrm{pH}$ with time. In figure (3), rate of reaction, activity, was directly proportional to enzyme amount in the area $(7.45-22.35 \mu 1)$. Then the rate of reaction started being nearly constant when the enzyme amount was increased above $22.35 \mu$. In order to provide sufficient enzyme amount for the next variables study, $30 \mu 1$ of enzyme volume was indicated as an optimum value for phosphoration of $1 \mathrm{~g} / \mathrm{l}$ glucose within reaction time of 60 seconds or more. 
$\mathrm{pH}$ value affects enzyme activity and optimum $\mathrm{pH}$ is the point where the enzyme is most active. In order to optimize $\mathrm{pH}$ of carrying buffer, enzyme activity was assayed with different $\mathrm{pH}$ values from 6.8 to 8.1 at constant at ATP concentration of $1.2 \mathrm{mM}, 20 \mathrm{mM}$ HEPES buffer, $2.2 \mathrm{mM}$ of $\mathrm{Mg}^{2+}$ and enzyme volume of $30 \mu 1$.Enzyme activity was indicated by observing rate of reaction which was calculated from obtained change in $\mathrm{pH}$ within 60 seconds. The results indicated that the enzyme activity was not efficient to reach the end point of glucose phosphorylation when the $\mathrm{pH}$ increased from 6.8 to 7.4. Further increase in $\mathrm{pH}$ indicated an end point with constant obtained change in $\mathrm{pH}$ for each buffer $\mathrm{pH}$ values between 7.6 and 8.1. These results can be shown in figure (4). Buffer capacity of different $\mathrm{pH}$ values were plotted in order to see its effect simultaneously. Figure (5) shows that buffer capacity increased with $\mathrm{pH}$ till $\mathrm{pH}$ value of 7.4. Then buffer capacity remained constant till $\mathrm{pH}$ value of 7.6. Buffer capacity started decreasing after $\mathrm{pH}$ 7.6. Since this study depend on measuring the change in $\mathrm{pH}$, optimum $\mathrm{pH}$ of 7.6 was indicated as the increase in obtained change in $\mathrm{pH}$ for $\mathrm{pH}$ value above 7.6 could be happened because of lowering in buffer capacity which can make the measurement unstable. This result is agreed with published optimum pH value 7.5 in range (7.5-9.0) (Sols et al. 1958).

Effect of buffer concentration on the obtained change in $\mathrm{pH}$ was studied. The higher buffer concentration is the lower obtained change in $\mathrm{pH}$. Variables such enzyme volume of $30 \mu 1, \mathrm{pH} 7.6$, ATP concentration of $1.2 \mathrm{mM}$ and $2.2 \mathrm{mM}$ of $\mathrm{Mg}^{2+}$ were held constant. In figure (6), increase buffer concentration from $30 \mathrm{mM}$ to $50 \mathrm{mM}$ caused a decrease in obtained change in $\mathrm{pH}$ from $(-23.74 \mathrm{mpH}$ to $-12.8 \mathrm{mpH})$ as the buffer capacity proportional with the buffer concentration. Since obtained changes in $\mathrm{pH}$ were sufficient for the mentioned above buffer concentrations, $40 \mathrm{mM}$ was chosen for the next experiments. This choice was to avoid any effect of varying ATP and $\mathrm{Mg}^{2+}$ concentrations on buffer stability during ATP- $\mathrm{Mg}^{2+}$ optimizing.

Enzyme volumes of $30 \mu 1,40 \mathrm{mM}$ buffer concentration at $\mathrm{pH} 7.6$ were applied to find optimum concentration of ATP and $\mathrm{Mg}^{2+}$. ATP and $\mathrm{Mg}^{2+}$ effects have to be studied simultaneously as they form a complex compound ATP$\mathrm{Mg}^{2+}$. First runs showed that increase the concentration of $\mathrm{Mg}^{2+}$ from 1.2 to $6 \mathrm{mM}$ had no big effect on the obtained change in $\mathrm{pH}$ as shown in figures ( 7 and 8$)$. The obtained changes in $\mathrm{pH}$ were in range between $(-15.5$ to $-14.5 \mathrm{mpH}$ ). On the other hand increase ATP concentration from $0.2 \mathrm{mM}$ to $1 \mathrm{mM}$ caused increase in obtained change in $\mathrm{pH}$ from $(-3.4$ to $-15 \mathrm{mpH})$. Then the obtained change in $\mathrm{pH}$ remained constant till ATP concentration of $1.4 \mathrm{mM}$ where the change in $\mathrm{pH}$ started to decrease noticeably as shown in figure(9). Therefore, $1 \mathrm{mM}$ ATP concentration was determined as optimum value.

Increase $\mathrm{Mg}^{2+}$ concentration till $2 \mathrm{mM}$, when the concentration of ATP is $1 \mathrm{mM}$, will increase the probability of ATP- $\mathrm{Mg}^{2+}$ compound formation to $89.2 \%$ of present ATP concentration. Any further increase in $\mathrm{Mg}^{2+}$ concentration didn't increase this probability (Storer and Cornish-Bowden, 1976). 1g/1, 5.5mM, of glucose sample was used in this study. This glucose concentration was diluted to $0.67 \mathrm{mM}$ by mixing chamber content i.e. buffer and enzyme. Therefore, ATP- $\mathrm{Mg}^{2+}$ compound concentration has to be equal or above 0.67 . Thus, $1.2 \mathrm{mM}$ ATP and $2.2 \mathrm{mM} \mathrm{Mg}^{2+}$ were indicated as optima for phosphorylation $1 \mathrm{~g} / \mathrm{l}$ glucose sample.

The mentioned obtained optimum operating conditions were used in calibration curve preparation for glucose concentrations range $(0-1 \mathrm{~g} / \mathrm{l})$. The results indicated a linear relationship with $(-15 \mathrm{mpH})$ maximum obtained change in $\mathrm{pH}$ as shown in figure (10).

\section{Conclusion}

This study develops using differential $\mathrm{pH}$ sensors device for low glucose concentration determination. The obtained calibration curve can be used in assaying low glucose concentration samples. Such kinds of samples are occurred often in cell culture experiments such as mammalian cells cultivation. Other advantage was obtained with developing measurement system by using HEPES buffer, which is widely used in cell culture i.e. buffer system of cultivation medium of mammalian cells. The results also showed that there is a need to optimize the required concentration of ATP- $\mathrm{Mg}^{2+}$ instead of optimizing ATP and $\mathrm{Mg}^{2+}$ separately.

\section{Acknowledgment}

This work was supported by Institute of Bioprocess Engineering at Erlangen University.

\section{References}

Barrado, E. Vela, M. Lapa, R. \& Lima, J. (1999). A FIA procedure for enzymatic determination of high glucose concentrations. Application to parenteral solutions analysis. Analusis. 27, 170-173.

Boduroglu, S. El Khoury, J.Reddy, D. Rinaldi, P. \& Hu, J. (2005). A colorimetric titration method for quantification of millimolar glucose in a pH 7.4 aqueous phosphate buffer. Bioorganic \& Medicinal Chemistry Letters. 15, 3974-3977. 
Ciantar, M. Spratt, D.Newman, H. \& Wilson, M. (2002). Development of an in vitro microassay for glucose quantification in submicrolitre volumes of biological fluid. J Periodontal Re, 37, 79-85.

Diessel, E. Willmann, S. Kamphaus, P. Kurte, R. Damm, U. \& Heise, H. (2004). Glucose Quantification in Dried-Down Nanoliter Samples Using Mid-infrared Attenuated Total Reflection Spectroscopy. Applied Spectroscop, 58, 442-450.

Lehninger, A. (1987). Principles of Biochemistry. (5th edition). Worth Publishers, Inc. New Yourk, Chapter 15, pp.397-404

Luzzana, M. \& Agnellini D. (2001). Enzymatic reaction for the determination of sugars in food samples using the differential pH technique. Journal of Analyst, 126, 2149-2152.

Luuzzana, M. \& Dossi, G. (1983). Measurement of glucose in plasma by a differential pH technique. Clinical Chemistry, 29, No.1, 80-85.

Luuzzana, M. \& Giardino, R. (1999). Urea determination in milk by a differential pH technique. Lait, 79, 261-267.

Mori, H. Ishida, M.\& Okamoto, S. (1999). Glucose Determination Using a Flow System with Enzyme Reactor and Application to Analysis of Glucose Content in Beverages. Journal of Health Science, 45(3) 126-129.

Mosca, A. Dossi, G. Luzzana, M. \& Rossi, L. (1981). Improved apparatus for the differential measurement of pH: Applications to the measurement of glucose. Analytical Biochemistry,112, 287-294.

Rogers, A. \& Gibon, Y. (2009). Enzyme Kinetics: Theory and Practice. In J. Schwender (ed), Plant Metabolic Networks. Springer Science+Business Media. LLC, Chapter 4, pp 71-103.

Rovida, E., Luzzana, M. \& Ripamonti, M. (1984). The determination of ethanol in whole blood by differential pH measurements. Scand.J.Clin.Lab.Invest, 44, 617-621.

Sols, A. Villar-Palasi, C. \& Asensio, C. (1958). Substrate specificity and some other properties of baker's yeast hexokinase. Biochimica et Biophysica Acta, 30, 92-101.

Storer, A. \& Cornish-Bowden, A. (1976). Concentration of MGATP2- and other Ions in Solution: Calculation of the true concentrations of species present in mixture of associating ions. Biochem. J., 159, 1-5.

Xie, L. Ye, X. Liu, D. \& Ying, Y. (2009). Quantification of glucose, fructose and sucrose in bayberry juice by NIR and PLS. Food Chemistry, 114, 1135-1140.

Wahjudi, P. Patterson, M. Lim, S. Yee, J. Mao,C. \& Lee W. (2010). Measurement of glucose and fructose in clinical samples using gas chromatography/mass spectrometry. Clin Biochem, 43, 198-207.

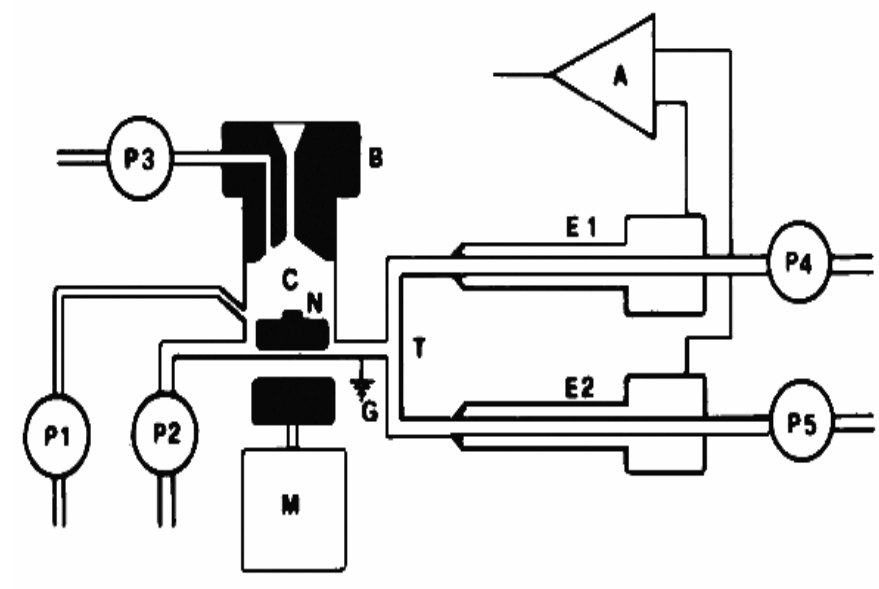

Figure 1. Schematic diagram of the differential $\mathrm{pH}$ analyzer system CL10.P1 to P5,peristaltic pumps; C, mixing chamber ;M, stirring motor ; N, magnetic stirrer ; E1 and E2, class capillary electrodes $\mathrm{pH}$ sensors ; A, differential amplifier. 


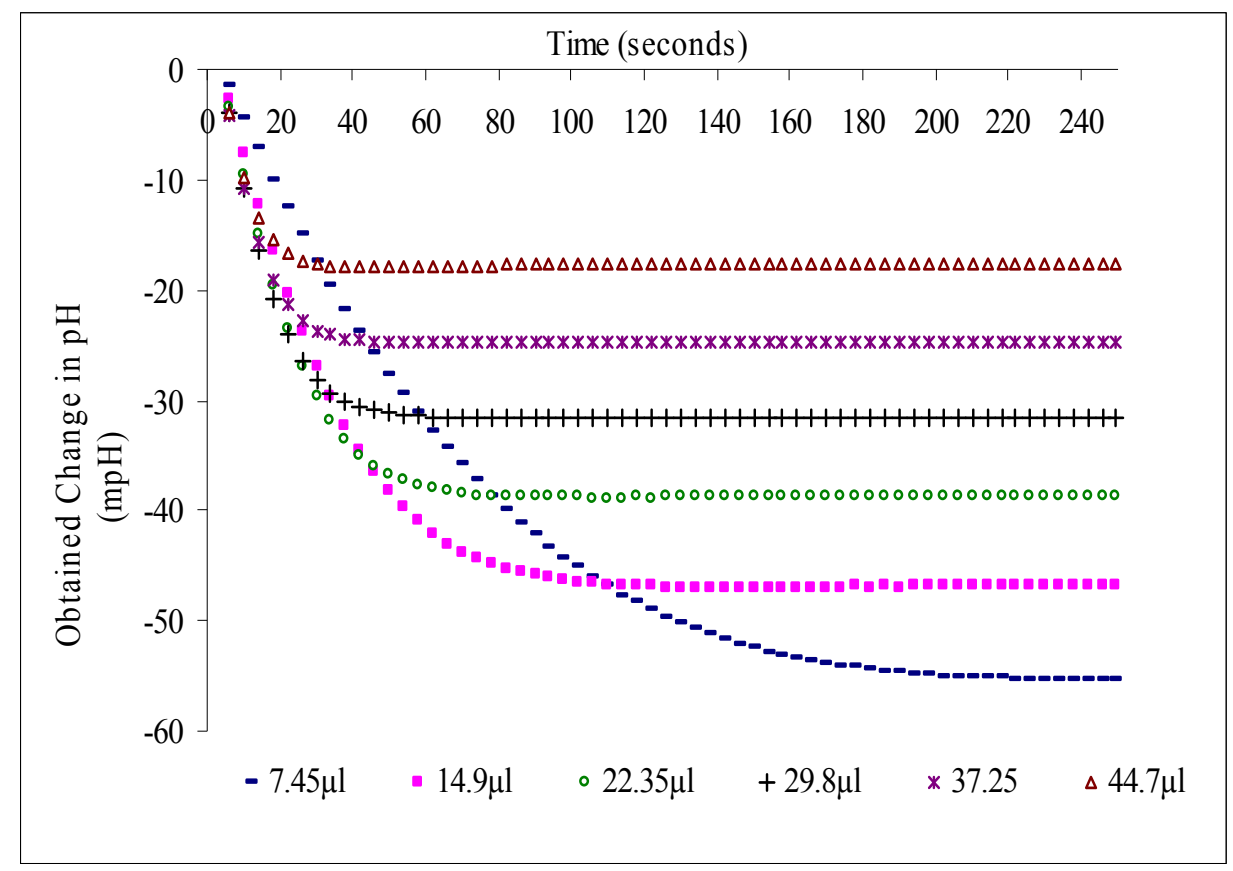

Figure 2. Enzyme volume effect on enzyme activity, obtained change in $\mathrm{pH}$, at constant other operating conditions such as ATP concentration of $1.2 \mathrm{mM}, 20 \mathrm{mM}$ HEPES buffer at $\mathrm{pH} 7.6$ and $2.2 \mathrm{mM}$ of $\mathrm{Mg}^{2+}$

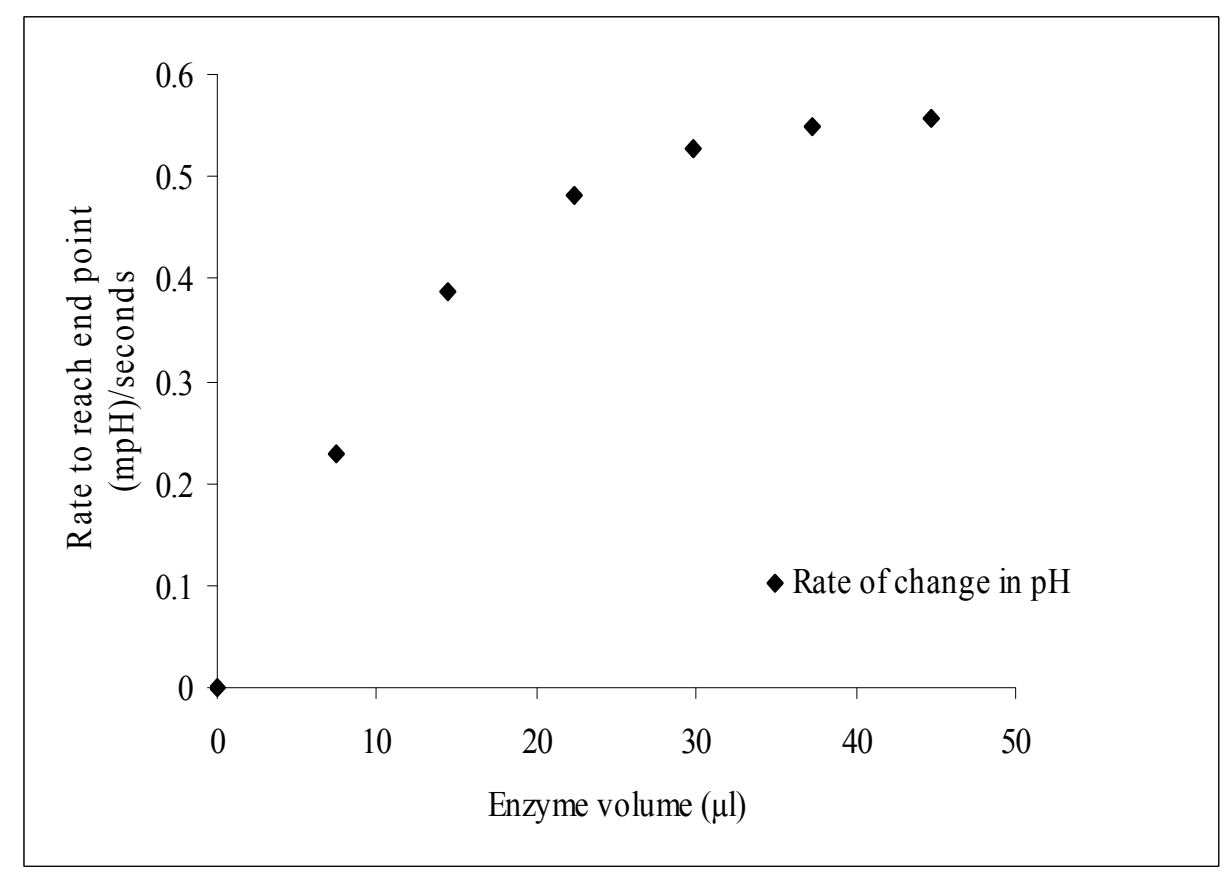

Figure 3. Enzyme volume effect on enzyme activity by measuring rate of obtained change in $\mathrm{pH}$ to reach end point of $1 \mathrm{~g} / \mathrm{l}$ glucose phosphorylation, at constant other operating conditions such as ATP concentration of $1.2 \mathrm{mM}, 20 \mathrm{mM}$ HEPES buffer at $\mathrm{pH} 7.6$ and $2.2 \mathrm{mM}$ of $\mathrm{Mg}^{2+}$ 


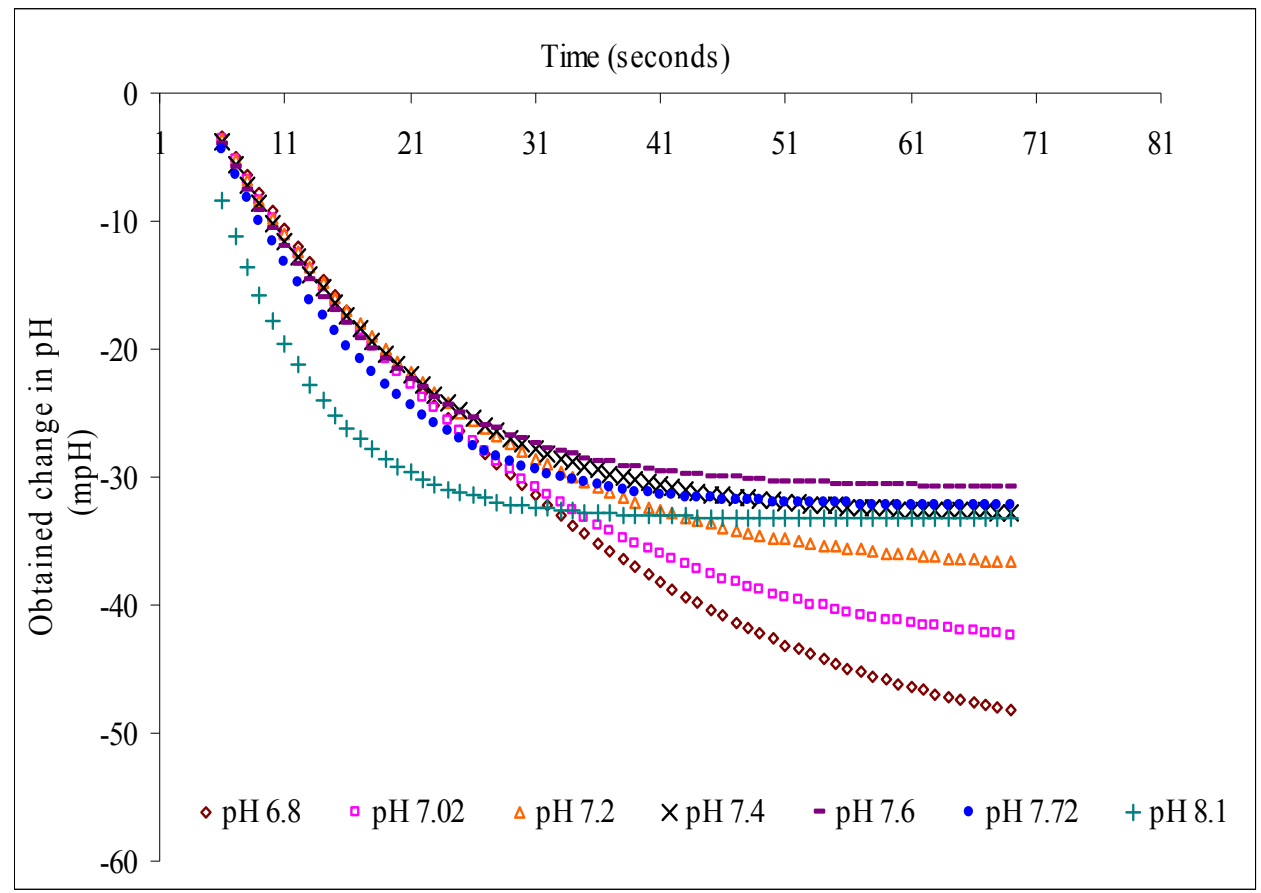

Figure 4. Effect of $\mathrm{pH}$ value on enzyme activity, obtained change in $\mathrm{pH}$, at constant other parameters such as ATP concentration of $1.2 \mathrm{mM}, 20 \mathrm{mM}$ HEPES buffer, $30 \mu \mathrm{l}$ enzyme volume and $2.2 \mathrm{mM}$ of $\mathrm{Mg}^{2+}$

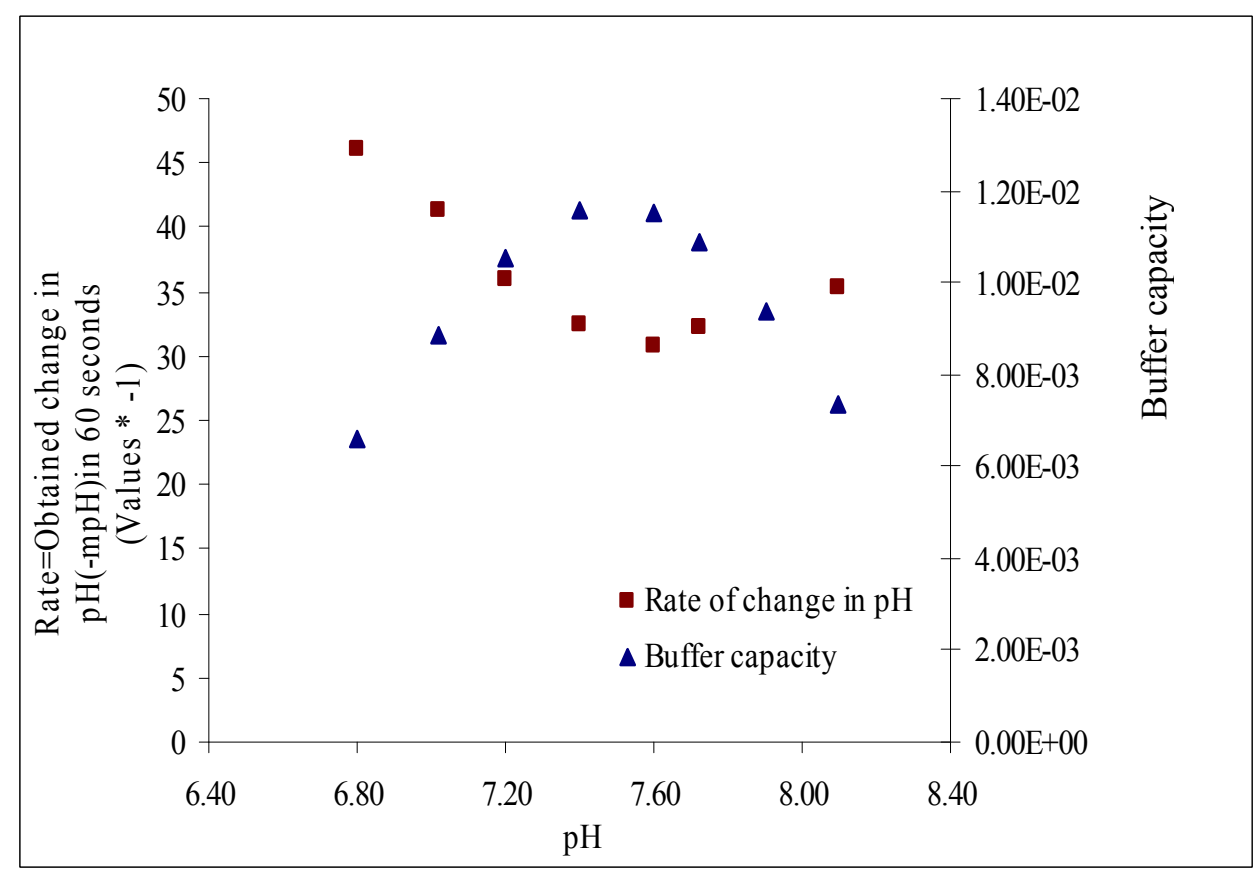

Figure 5. Effect of $\mathrm{pH}$ value and buffer capacity on obtained change in $\mathrm{pH}$ within 60 seconds reaction time at constant ATP concentration of $1.2 \mathrm{mM}, 20 \mathrm{mM}$ HEPES buffer, $30 \mu 1$ enzyme volume and $2.2 \mathrm{mM}$ of $\mathrm{Mg}^{2+}$ 


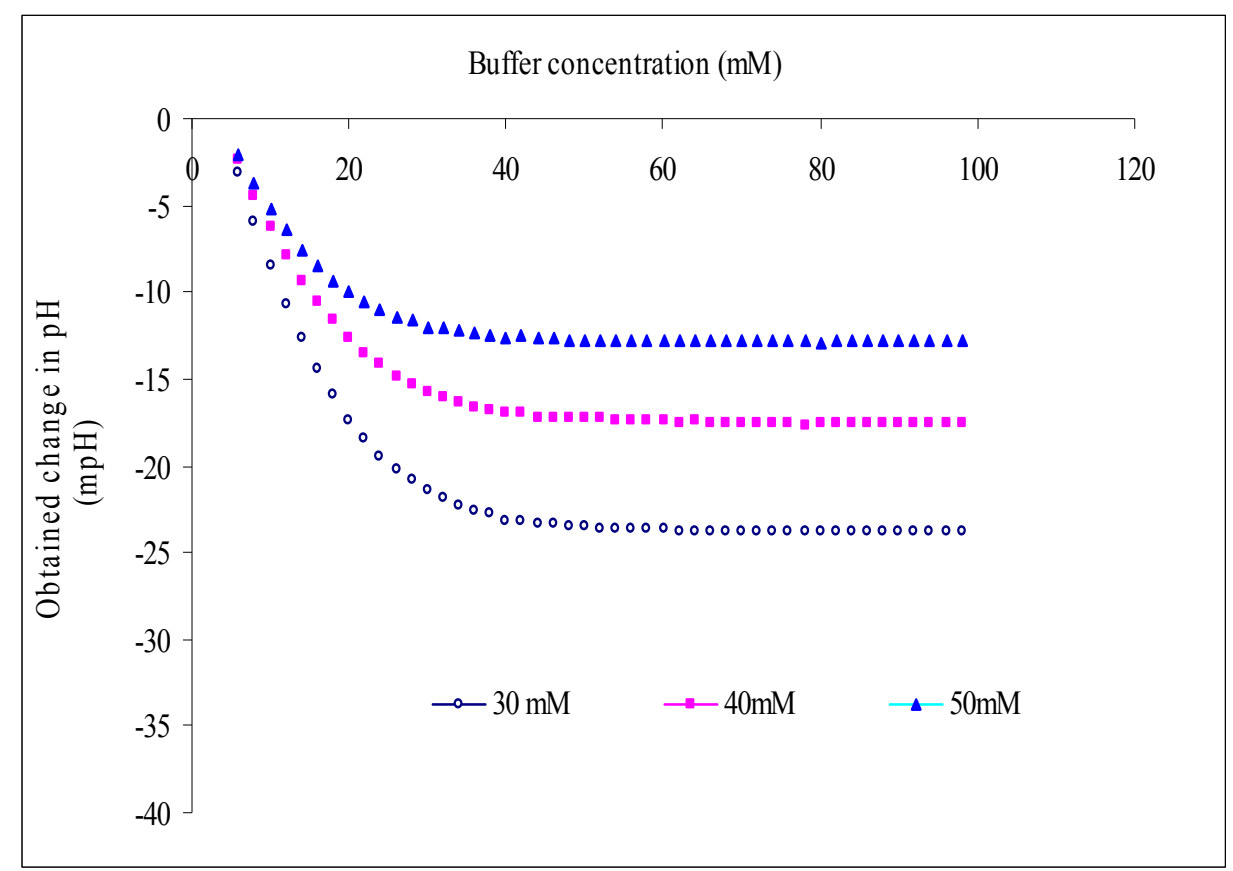

Figure 6. Buffer concentration effect on obtained change in $\mathrm{pH}$ at constant ATP concentration of $1.2 \mathrm{mM}$, HEPES buffer of $\mathrm{pH} 7.6,30 \mu 1$ enzyme volume and $2.2 \mathrm{mM}$ of $\mathrm{Mg}^{2+}$

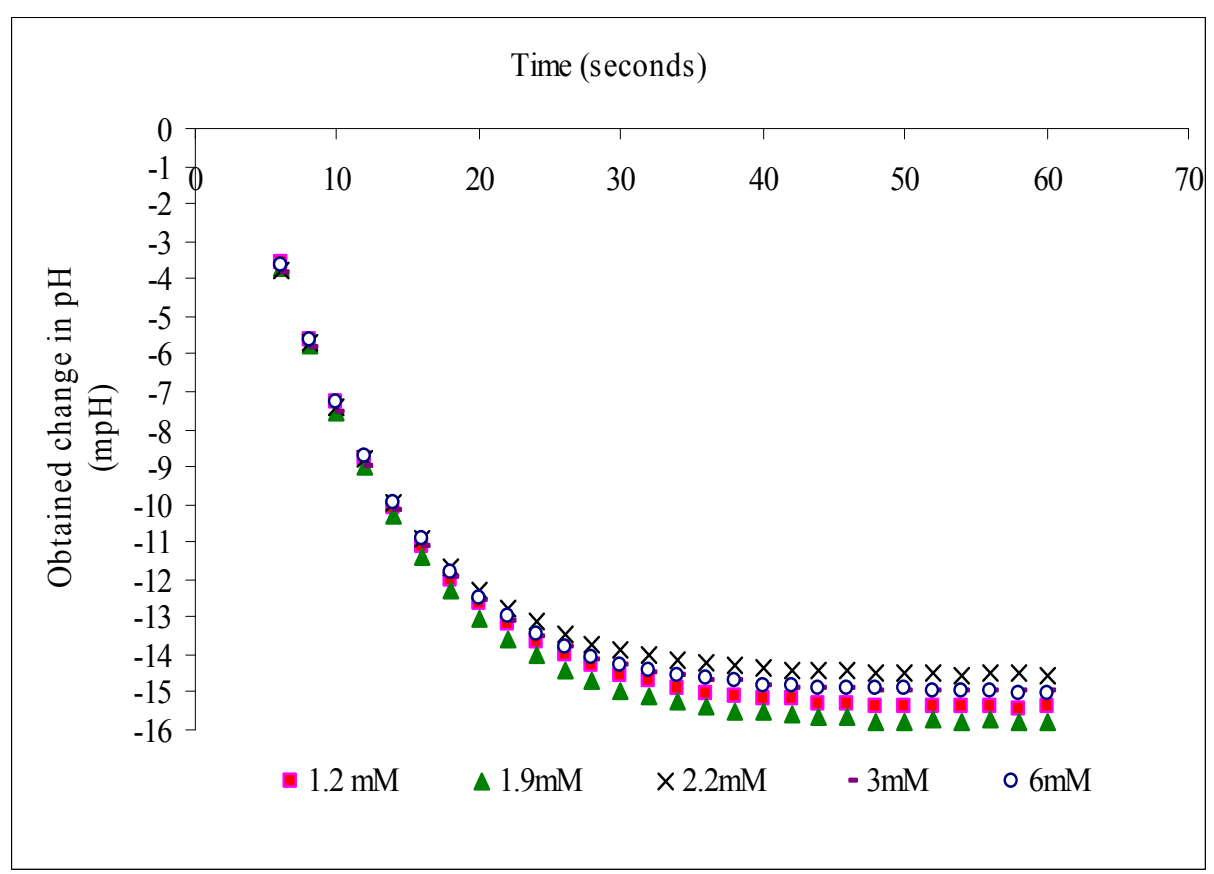

Figure 7. $\mathrm{Mg}^{2+}$ concentration effect on obtained changes in $\mathrm{pH}$ at constant ATP concentration of $1.2 \mathrm{mM}, 40 \mathrm{mM}$ HEPES buffer, pH 7.6 and $30 \mu 1$ enzyme volume 


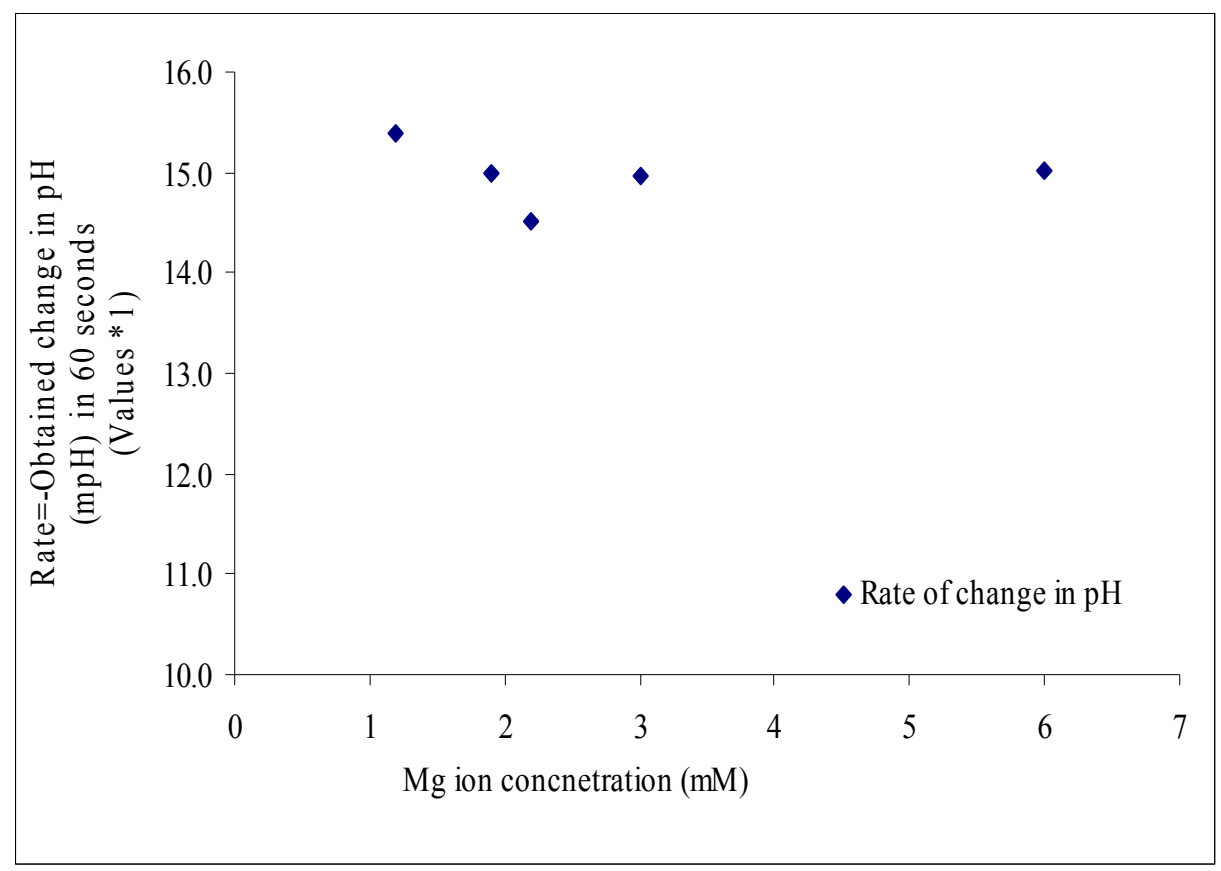

Figure 8. $\mathrm{Mg}^{2+}$ concentration effect on obtained change in $\mathrm{pH}$ at constant ATP concentration of $1.2 \mathrm{mM}, 40 \mathrm{mM}$ HEPES buffer, $\mathrm{pH} 7.6$ and $30 \mu 1$ enzyme volume

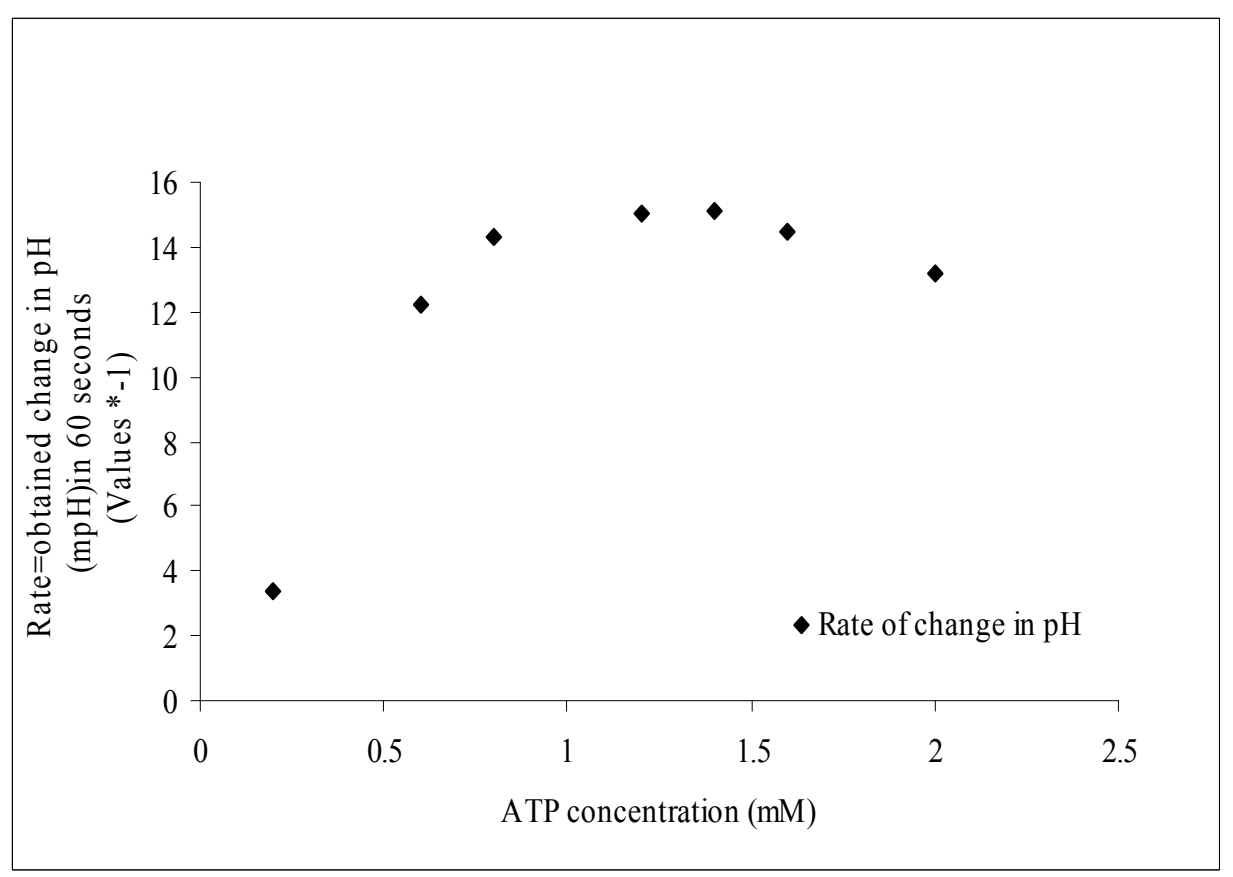

Figure 9. ATP concentration effect on enzyme activity, obtained change in $\mathrm{pH}$, at constant operating conditions of 40mM HEPES buffer concentration, $\mathrm{pH} 7.6,30 \mu 1$ enzyme volume 


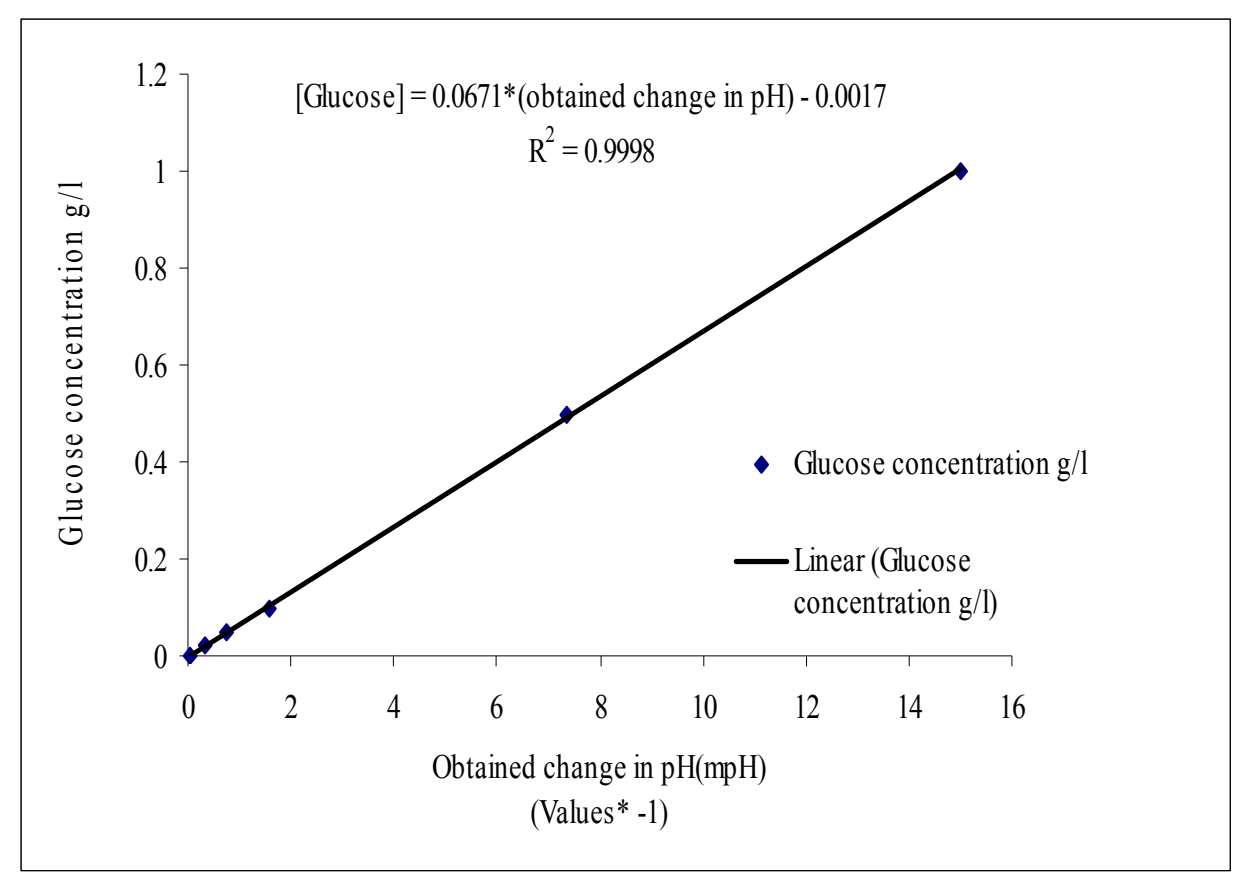

Figure 10. Calibration curve of glucose concentrations (0-1 g/l) against obtained change in $\mathrm{pH}(\mathrm{mpH})$ within Differential pH Sensors Device. Optimum operating conditions of ATP concentration of $1.2 \mathrm{mM}, 40 \mathrm{mM}$ HEPES buffer concentration, $\mathrm{pH} 7.6,30 \mu \mathrm{l}$ enzyme volume and $2.2 \mathrm{mM}$ of $\mathrm{Mg}^{2+}$ were applied 